[Vicino Oriente XXII (2018), pp. 111-120]

\title{
ON PHOENICIANS IN PTOLEMAIC CYPRUS: A NOTE ON CIS I 95*
}

\author{
Federico Giusfredi - University of Verona
}

In this paper, I will discuss some aspects of the Greek-Phoenician bilingual inscription CIS I 95 from Lapethos (Cyprus). I will concentrate on the form, contents and date of the inscription, and I will attempt an interpretation of the linguistic and cultural context in which the text was composed.

Keywords: Phoenician; Greek; Cyprus; bilingual; contact

\section{INTRODUCTION}

The rock inscription CIS I 95 (= KAI I, 42) is a bilingual dedication to 'nt/Athene (synchretically identified with each other in a multicultural scenario), written in Phoenician and Greek and made on account of Ba'alšillem/Praxidemos. Discovered in the 1860s in Lapethos (Cyprus), it has recently been discussed by Maria Giulia Amadasi Guzzo ${ }^{1}$ in a long and highly informative contribution, that includes photographs of the whole inscription and details illustrating the Greek and Phoenician texts separately.

\section{THE TEXT}

The Greek version of the text, according to the transcription and to the photographs offered by the Italian scholar (who also compares and quotes the works by Melchior de Vogüé $^{2}$ and Paul Schröder, ${ }^{3}$ thereby eventually correcting the misleading line-division presented in the KAI I, 42), runs as follows. I maintain capital letters instead of normalizing the transcription because of the uncertain status of some problematic portions of the text:

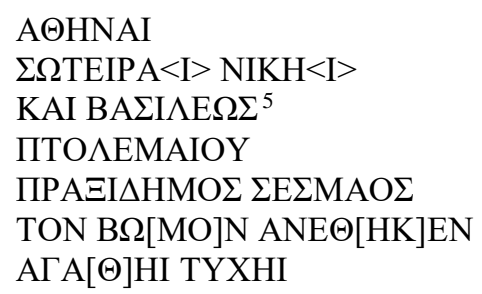

A@HNAI

KAI BA $\Sigma \mathrm{I} \Lambda \mathrm{E} \Omega \Sigma^{5}$

ПTO $\Lambda$ EMAIOY

TON B $\Omega[\mathrm{MO}] \mathrm{N}$ ANE@[HK]EN

АГА $[\Theta] H I$ TYXHI

\author{
To Athene \\ Savior and Victory [dative omitted?] ${ }^{4}$ \\ and of the king [sic!] \\ Ptolemy [genitive!] \\ Praxidemos of Sesma \\ the altar posed \\ for/with good luck
}

\footnotetext{
* The present paper is part of the project PALaC, that has received funding from the European Research Council (ERC) under the European Union's Horizon 2020 research and innovation programme (grant agreement $n^{\circ}$ 757299). I wish to thank Paola Cotticelli-Kurras, Attilio Mastrocinque and Valerio Pisaniello for discussing with me the first drafts of this contribution. The responsibility for the contents of this paper, however, belongs entirely to me.

Amadasi Guzzo 2015.

De Vogüé 1867.

Schröder 1869.

4 The omission of the dative ending may actually be explained as a case of unwritten iota, a practice that seems to become common starting from the late $3^{\text {rd }}$ and $2^{\text {nd }}$ century BC. See below, paragraph 4 .

5 Philippa Steele 2013, 208, mistakenly transcribes a nominative BA $\Sigma$ I $\Lambda$ EY $\Sigma$.
} 
The Phoenician version is only slightly different in its syntax and contents:

L'NT 'Z HYM
WL'DMLKM PTLMYŠ
B‘LŠLM BN [S]SMY
YQDŠ [']T MZBH
[L]MZL N'M

\author{
To 'nt force(?) of life(?) \\ and to Ptolemy the lord of the kings \\ Ba'alšillem son of Sesmay \\ consecrated the altar \\ for/with good luck
}

\section{3. 'NT/ATHENE IN CYPRUS}

I will not attempt to solve the problem of the unclear epithet of ' $\mathrm{nt}$ in the Phoenician version (' $\mathrm{Z} H Y M$; or M'Z HYM according to the KAI I, 42, with a s integrated at the onset of the second word of line 1 , of which no traces are visible); I will simply note that the very likely meaning "force(?)/fortress(?) of life(?)/of the livings(?)" does not seem to exactly

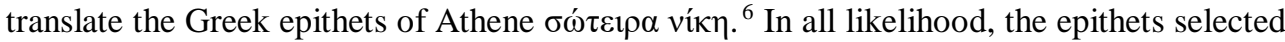
and employed in the two versions derive from two different and independent formulaic traditions, even though it must be stressed that the Phoenician one is so far unparalleled in the Ugaritic and West Semitic corpora. ${ }^{7}$ Amadasi Guzzo's hypothesis, ${ }^{8}$ according to which the epithet would be coined in connection with the occasion of the dedication of the text is flawless and bases on solid comparative material.

As for the general problem of the syncretistic identification of Athene and 'nt, it must be stressed that Cyprus seems to be the specific environment in which the two goddesses were first associated. ${ }^{9}$ Even though the occurrences of the divine name are not many, the cult of 'nt may have spread on the island at least starting with the Phoenician colonization in the mid- $9^{\text {th }}$ century BC, ${ }^{10}$ but it became indeed more relevant with the political events of the $5^{\text {th }}$ century, as discussed in a recent contribution by Maria Bianco and Corinne Bonnet (no epigraphic occurrences of the name exist before this phase). ${ }^{11}$ While the reasons for the identification may depend on some similar traits of the two divine figures (most notably, the functions of déesse ... guerrière mentioned by Amadasi Guzzo 2015, 33), and perhaps to a phonetic similarity of the two divine names, no clear evidence exists pointing to a diffusion outside the island (the only exception being some personal names); hence, it should be regarded to as a local fact.

Further evidence for a local identification of ' $n$ t and Athene is provided by the presence of an inscribed spear spike that mentions the name of the Semitic Goddess, found in the

\footnotetext{
See the discussion in Amadasi Guzzo 2015, 34.

On the epithets in the Ugaritic corpus, cf. Aicha Rahmouni 2008.

Amadasi Guzzo 2015, 33-37.

9 Edward Lipinski 1995, 312 ff.; for a somewhat outdated fully synchretistic approach see Robert Du Mesnil du Buisson 1973, in pc. 54 ff. On 'nt in the West Semitic pantheon cf. Helmer Ringgren 1979, 214-235. Further on the penetration of the cult of Athene in the Phoenician population in Cyprus, Bianco - Bonnet 2016.

10 Cf. the case study in Andreas Demetriou 2001. An earlier date for the presence of Phoenician documents in Cyprus may be assumed if one considered the short inscription discussed by Olivier Masson and Maurice Snyzcer 1972, 192 and Marguerite Yon, 2004, 192, to be dated to the $11^{\text {th }}$ century BCE. Cf. however the remarks by Steele 2013, 175.

11 Bianco - Bonnet 2016, 167-173.
} 
sanctuary of Athene in Idalion. ${ }^{12}$ The only preserved portion of text runs as follows: l-' $n t$ "To 'nt". The item can be dated to the mid- $5^{\text {th }}$ century BC, while an inscription by King Baalmilk II, also mentioning the Goddess, is slightly later:

[... byr]ḥ mrp'm bšnt šlš 3 lmlky b‘lmlk mlk kty w’dyl bn mlk 'zb‘l mlk kty w'dyl bn mlk b'lmlk [m] [k] kty m'q 'z ytn [wyqď̌ '] l 'z[b']l [m]lk [kty w]'dyl bn mlk b'lmlk mlk kty lrbty l'nt k [šm‘'... $]^{13}$

“[...in the mo]nth mrp'm, in the third year of his reign, Baalmilk, king of Kition and Idalion, son of Ozibaal, king of Kition and Idalion, son of Baalmilk, king of Kition, donated [and dedicated (?)] this temenoswall(?) ${ }^{14}$ (of the sanctuary), on behalf of Ozibaal, king [of Kition and] Idalion, son of Baalmilk, king of Kition, to his lady, to 'nt, for [she listened (to his voice)]" 15

Both documents demonstrate that an at least double cultic function of the sanctuary dates back to an earlier phase than the one in which the bilingual inscription CIS I 95 was composed (regardless of the precise identification of the Ptolemy mentioned in the text, it is clear that the 310s are the unquestionable terminus post quem).

\section{THE HISTORICAL SCENARIO AND THE DATE OF THE TEXT}

M.G. Amadasi Guzzo, generally followed by M. Bianco and C. Bonnet, ${ }^{16}$ dates the text to the time of Ptolemy $1^{\text {st }}$ "king" in the Greek text, "lord of the kings" in the Phoenician one), who gained control over the island in the early years of his reign, sedated a rebellion in $313 \mathrm{BC}$, lost the island to the Antigonids for a decade in 306 BC and won it back in 294 BC. ${ }^{17}$ She also discusses the problem of whether the original version of the text was the Greek or the Phoenician one, and tries to analyze the correspondence between the Greek and the Phoenician versions of the personal name ПPA $\Xi \mathrm{I} \Delta \mathrm{HMO} / \mathrm{B}{ }^{`} \mathrm{LS} L \mathrm{LM}$. As regards the original version of the dedication, no conclusive proposal is made, while it is duly observed that the structure of the Phoenician version seems to follow the Greek one. More specifically, the order of the words is rather atypical for Phoenician dedications, where the direct object usually precedes the verb, which, in turn, precedes the subject. At the same time, M.G. Amadasi Guzzo duly acknowledges the presence of several morphosyntactic

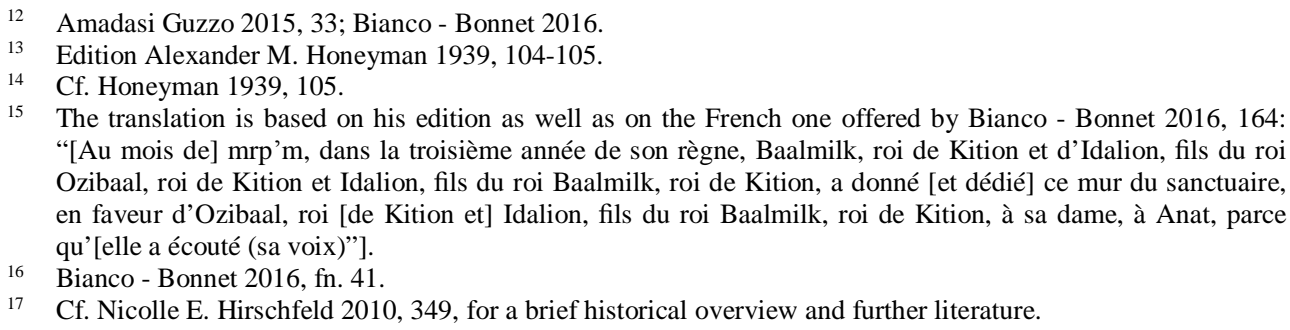


mistakes in the Greek version, ${ }^{18}$ which, according to her analysis, would point to the fact that the scribe may have been more accustomed with the traditional Cyprian syllabary than with the Greek alphabet, the use of which was still an emerging practice on the island.

While this scenario is certainly not implausible, it must be stressed that the peculiarities of the Greek version of the text seem to pertain to the case-syntax rather than to the graphemic rendering of the phonetics and morphology of the language (which may differ in a linear script and in an alphabetic one). More specifically, the mistakes, or uncertainties, that occur seem to include:

1) possibly omitted dative endings in $\Sigma \Omega T E I P A<\mathrm{I}>$ and $\mathrm{NIKH}<\mathrm{I}>$ in line 2 (but see below for further discussion);

2) either syntactically aberrant KAI in line 3 or

3) genitive in place of a dative in lines 3 and 4 .

In case the word KAI in line 3 was indeed misplaced, the genitives in lines 3 and 4 would be correct, and the text would read

\section{A@HNAI \\ $\Sigma \Omega$ TEIPA $<$ I $><$ KAI $>$ NIKH $<$ I $>$ \\ $[[\mathrm{KAI}]] \mathrm{BA} \Sigma \mathrm{I} \Lambda \mathrm{E} \Omega \Sigma$ \\ ПТO $\Lambda$ EMAIOY}

\author{
To Athene \\ Savior and to the Victory \\ of the king \\ Ptolemy
}

This solution, however, is slightly ad hoc, textually unusual and not consistent with the division of the lines, which seem to group together the two epithets of Athene in line 2. Therefore, a more convincing interpretation might be that the name and title of Ptolemy should have been in dative rather than in genitive, and that the two morphological cases of Greek were confused by the scribe: "To Athene Savior Victory and to King Ptolemy...". That Ptolemy received the dedication together with the Goddess Athene may be surprising, but if one compares the Phoenician version of the inscription this solution would work just fine. If in this case one wanted to assume that, by receiving the dedication, Ptolemy had to be already divinized, it should be noticed that, while it is true that a proper cult of Ptolemy $1^{\text {st }}$ was only established between the 280s and the end of the $3^{\text {rd }}$ century BC in Egypt, earlier traces of his divinization are attested. ${ }^{19}$

Furthermore, at least a third solution may be proposed, by improving Amadasi Guzzo's suggestion that the genitive would indicate that the text belonged to Ptolemy rather than

18 It is worth noting that the other alphabetic Greek-Phoenician bilingual text that was found in Cyprus, the funerary stele of a Lycian man named Smyrnos (text in Carlo Consani 1988, 56; Yon 2004, 274; Steele 2013), does not display evident mistakes in the Greek version, while some uncertainties may motivate the spelling of the personal name in the Phoenician one. A third case of epigraph carrying alphabetic Greek and Phoenician signs is the Dhromolaxia stela; here, however, the texts are epigraphically independent from each other, with the Phoenician one dating back to the $4^{\text {th }}$ century BC and the Greek one added in the $1^{\text {st }}$ century BC (cf. Consani 1988, 46).

19 Cf. Tomasz Grabowski 2014, 23 ff. 
being dedicated to him. ${ }^{20}$ If a mistake took place in the Greek version of the text, and it almost certainly did, the scribe might have overlooked the preposition vi $x \dot{\rho}$, quite common in this kind of dedications. ${ }^{21}$ If this were the case, we would have to restore the incipit of the Greek text as follows:

\section{A@HNAI \\ $\Sigma \Omega$ TEIPA $<$ I $>$ NIKH $<$ I $>$ \\ $\mathrm{KAI}<\mathrm{Y \Pi EP}>22$ BA $\Sigma \mathrm{I} \Lambda \mathrm{E} \Omega \Sigma$ ПТО $А$ ЕАIOY}

To Athene

Savior Victory

and for the king

Ptolemy

I shall commit myself neither to this solution, nor to the idea that the scribe merely confused dative and genitive; I do, however, consider the suggestion that the KAI should be moved before the word $\mathrm{NIKH}<\mathrm{I}>$ to be unconvincing, because it is overcomplicated and would make little sense when one compares the Phoenician version.

In any case, one can very easily conclude that no compelling reasons exist to assume that the Ptolemy mentioned in the text was the first member of the dynasty and first ruler of his name. Such identification can only be based on speculation about the historical occasion in which the stone was carved. There is no clear reference to specific military events. As for the identification of ПPA $\Xi \mathrm{I} \triangle \mathrm{HMO} \Sigma$ with the priest of Poseidon mentioned in another text from Lapethos, ${ }^{23}$ discussed by Edward Lipiński, ${ }^{24}$ it is not supported by conclusive evidence and, even assuming that the two figures were indeed the same person, a high priest who was active in the 290s could very well have been active also a dozen of years later under a different king.

As for the paleography, there are no strictly diagnostic elements in the Greek text that would support or exclude a specific date. ${ }^{25}$ Broken-bar alpha, that would tend to exclude the earlier decades of the Ptolemaic age, is not used in the text. On the other hand, the omission of the dative case markers in line $2(\Sigma \Omega$ TEIPA $<\mathrm{I}>\mathrm{NIKH}<\mathrm{I}>)$, rather than a mistake, may be a case of omission of iota adscript ( $\sigma \omega \tau \varepsilon i ́ \rho \alpha$ víkn), a practice that became common starting with the mid $3^{\text {rd }}$ and $2^{\text {nd }}$ century BC.

Paleographic criteria, in any case, are all but a precise tool when one tries to disambiguate between decades. In general, both from the perspective of the text contents and basing on the shape of the Greek letters, no firm conclusion can be reached as far as the identity of King Ptolemy mentioned in line 3 (// line 2 in Phoenician) and the exact date of the inscription are concerned. Based on the historical events that took place on the island, the first decades of the $3^{\text {rd }}$ century BC simply represent the best guess one can make.

Amadasi Guzzo 2015, 32.

21 On the inscriptions that contain a divine name in dative, the personal name of the king in genitive preceded by $\dot{v} \boldsymbol{\varepsilon} \rho$, and the name of the person who made the dedication in nominative ("to God's Name, on account of King's Name, Mr. So-and-so”), cf. Eleni Fassa 2013, 127 f. (with reference to previous literature).

22 Or: [[KAI]] $<\mathrm{Y} \Pi \mathrm{IEP}>\mathrm{BA} \Sigma \mathrm{I} \Lambda \mathrm{E} \Omega \Sigma$, in case the KAI mistakenly replaced the preposition.

23 ArchPap 13, 14.

24 Lipiński 1987, 405.

25 I thank Prof. Attilio Mastrocinque for his suggestions as regards the shape of the Greek letters used in the text under investigation. 


\section{THE LINGUISTIC SCENARIO}

Whatever the solution of the KAI-riddle in line 3, it is clear that the document exhibits a complex pattern of language contact that does not follow a single trajectory from one version to the other. In general, lexical loans move from prestige languages the popular substrata; morphosyntactic interferences, on the other hand, penetrate from the native languages of the scribes into the higher diaphasic codes. In the case of CIS I 95, however, the clause syntax of the Phoenician text is probably influenced by Greek, while the morphosyntax of the Greek text is influenced by the Semitic one, which points to a nonlinear pattern of mutual interference.

The confusion between genitive and dative, regardless of the possible omission, in this case, of a preposition $\dot{x} \varepsilon \dot{\varepsilon} \rho$, is a mistake that can easily happen in multilingual scenarios, with another example being available in Sicily in the text IG XIV, 297 (the so-called "stone-cutter's inscription" from Palermo), where, in the Latin version, a preposition qum is followed by a surprising genitive operum publicorum. ${ }^{26}$

\begin{tabular}{|c|c|}
\hline$\sigma \tau \tilde{\eta} \lambda \alpha \imath$ & TITULI \\
\hline$\dot{\varepsilon} v \theta \alpha ́ \delta \varepsilon$ & HEIC \\
\hline 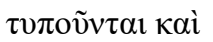 & ORDINANTUR ET \\
\hline$\chi \alpha \rho \alpha ́ \sigma \sigma o v \tau \alpha \iota$ & SCULPUNTUR \\
\hline 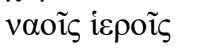 & AIDIBUS SACREIS \\
\hline 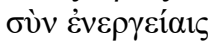 & QUM OPERUM \\
\hline 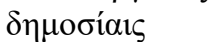 & PUBLICORUM \\
\hline
\end{tabular}

"Inscriptions here laid out and carved for sacred buildings as well as for public works” (translation by John Bodel 2015, 748)

In a very recent and still unpublished paper, Marta Capano (2018) argued that since neither the Latin version nor the Greek one is flawless, the peculiarities of this bilingual inscription may depend on the fact that the scribe could have been a Neo-Punic speaker, a hypothesis that I find extremely reasonable in the multicultural and multilingual environment of Sicily in the late Roman Republic or in the early Empire, and that, if correct, would provide good comparative material for the discussion of CIS I 95.

Indeed, if the role of a Semitic language can only be indirectly hypothesized in the case of the Palermo bilingual, in CIS I 95 Phoenician is actually one of the two languages that were employed by the scribe. This makes the hypothesis that Phoenician was the native language of the scribe even more convincing: the uncertainty in the use of the Greek case syntax can be relatively easily explained by the fact that in Phoenician the two "cases" do not exist, and the distinction is marked syntactically (by the status constructus and the preposition l- respectively).

26 The Greek version also presents some rather obscure features, as pointed out by John Bodel 2015, 748. Cf also Patrick James - Moreed Arbabzadeh 2018, who suggest that the Greek version was a translation of the Latin one, a hypothesis that I find only partly convincing. Previous studies are duly listed and discussed by Olga Tribulato 2012, 132-133. 
In general, however, a methodological observation is now in order. The question for the "original versions" of ancient bilingual epigraphs is very often methodologically flawed: with few exceptions, one should not consider bilingual documents as a couple formed by a text and by a translation thereof; rather, in most cases, the whole bilingual is itself a document, and the way it was composed must be analyzed considering the historical and linguistic evidence for contact. A more sensible approach is therefore not to look for a "model" and a "replica" in a translation act, but rather to try and understand: (1) who was the person who dedicated the inscription; (2) who was the scribe who composed the text; (3) whether or not more scribes were involved.

\section{HOW THE TEXT WAS COMPOSED}

When possible, the answer to the first question should be based on onomastics. The attempt by M.G. Amadasi Guzzo at demonstrating that the ПPA $\Xi I$-component of the Greek version of the name and the ŠLM-component of the Phoenician one are semantically similar is brilliant, ${ }^{27}$ but unnecessary.

ПPA $\Xi \mathrm{I} \triangle \mathrm{HMO} \Sigma$, in my opinion, is quite evidently an attempt at reproducing the phonetics of the Phoenician name by using a similar existing Greek name (the metathesis al $>$ PA [ra] and the rendering of $l$ by $\Delta[\mathrm{d}]$ do not speak against this process of adaptation/interpretation). ${ }^{28}$ This and the fact that the name of the father, [S]SMY, is certainly Phoenician (as correctly shown by M.G. Amadasi Guzzo ${ }^{29}$ ) are more than enough evidence to confirm that the man who dedicated the inscription was a Phoenician, and that his name was simply B'LŠLM.

As for the second and third questions, there is certainly no indication that more than one scribe worked on the inscription (even though the possibility cannot be excluded). Indeed, the interference phenomena are easily explained by assuming that the scribe was, in fact, a native Phoenician speaker with a second-language competence of Greek. Indeed, the order of the elements in the texts does not require to be explained strictly syntactically: first, the Goddess is mentioned, then the King, and eventually the proper dedication follows (here, however, the Semitic syntax does seem to be influenced by the order of Greek). While this pattern of textual elements, dictated by epigraphic informational prominence, is the same in the two versions, it must be conceded that the Greek one was almost certainly written before the Phoenician one, because it precedes it vertically on the rock support. It is also unquestionable that the Greek formula $\mathrm{A} \Gamma \mathrm{A}[\Theta] \mathrm{HI}$ TYXHI ("for/with good luck", with a propitiatory intent) is translated and adapted quite literally in the Phoenician text, and its

27 See Amadasi Guzzo 2015, 38, who suggests for both the Greek and the Phoenician morph a connection with the semantic fields "payer", "récompenser".

28 The Greek name is attested 10 times in inscriptions that were discovered in different areas of Greece and Asia Minor: IG XI,2 203, 244, 287, XII,9 244; ID 298; SEG 34, 897; ArchPAP 13, 14; Teos 34,5 (twice). As regards the Phoenician name, see the references by Amadasi Guzzo, 2015, 32 ${ }^{12}$; cf. also Cacqot and Masson 1968, 317-320.

29 Cf. Amadasi Guzzo 2015, 38, with reference to previous studies. 
position in the inscription is typical for Greek dedications, rather than Phoenician ones. ${ }^{30}$ This may be consistent with the fact that Greek was the language of the ruling dynasty, and political reasons may have required it to be on top and to follow a specific formulaic pattern, that was then mimicked by the Phoenician version.

\section{CONCLUSION}

In conclusion, while no version, as I argued, should be regarded to as the "original one", what is left to say is that the morphosyntactic mistakes or uncertainties in the Greek version strongly support the idea that the scribe started by carving the Greek dedication, but was in all likelihood a native speaker of Phoenician, and had an imperfect competence of Greek. Phoenician was also the man who had the inscription dedicated, while Greek was, in this case, the language of the political élite dominating the island under the Ptolemaic dynasty. As for the exact historical context, no conclusive element exists to support an identification of the Ptolemy mentioned in the text with the diádokhos and founder of the Greek dynasty of Egypt, and a connection with the military events that took place in Cyprus between 313 and $293 \mathrm{BC}$ is, at present, very likely but still speculative.

\section{ABBREVIATIONS}

ArchPap Archiv für Papyrusforschung und verwandte Gebiete, Berlin, 1901-.

CIS Corpus Inscriptionum Semiticarum, Paris, 1867-1962.

ID Inscriptions de Délos, Paris, 1926-1972.

IG XI,2 Félix Durrbach, 1912. Inscriptiones Graecae XI. Inscriptiones Deli, fasc. 2, Berlin.

IG XII,9 Erich Ziebarth, 1915. Inscriptiones Graecae XII. Inscriptiones Euboeae insulae, fasc. 9, Berlin.

IG XIV Georg Kaibel, 1890. Inscriptiones Graecae, XIV. Inscriptiones Siciliae et Italiae, additis Galliae, Hispaniae, Britanniae, Germaniae inscriptionibus, Berlin 1890.

KAI I Donner, H., Rollig, W. 1962. Kanaanäische und Aramäische Inschriften, Band I, Wiesbaden.

Teos Donald F. McCabe, 1991. Teos Inscriptions. Texts and List, The Princeton Project on the Inscriptions of Anatolia, The Institute for Advanced Study, Princeton.

\section{REFERENCES}

AMADAsi GuZzo, M.G.

2015 Encore CIS I 95 et les divinités guerrières à Chypre: Orientalia 84/1 (2015), pp. 29-40.

BIANCO, M. - BONNET, C.

2016 Sur les traces d’Athéna chez les Phéniciens: Pallas 100 (2016), pp. 155-179.

30 One might also wish to compare the occurrence of the obviously different but functionally similar propitiatory sequence MŠ LN'M at the beginning of a monolingual Phoenician inscription on the base of a statuette also from Lapethos (see Honeyman 1941; cf. also Steele 2013, 189, with a debatable translation of the formula). 


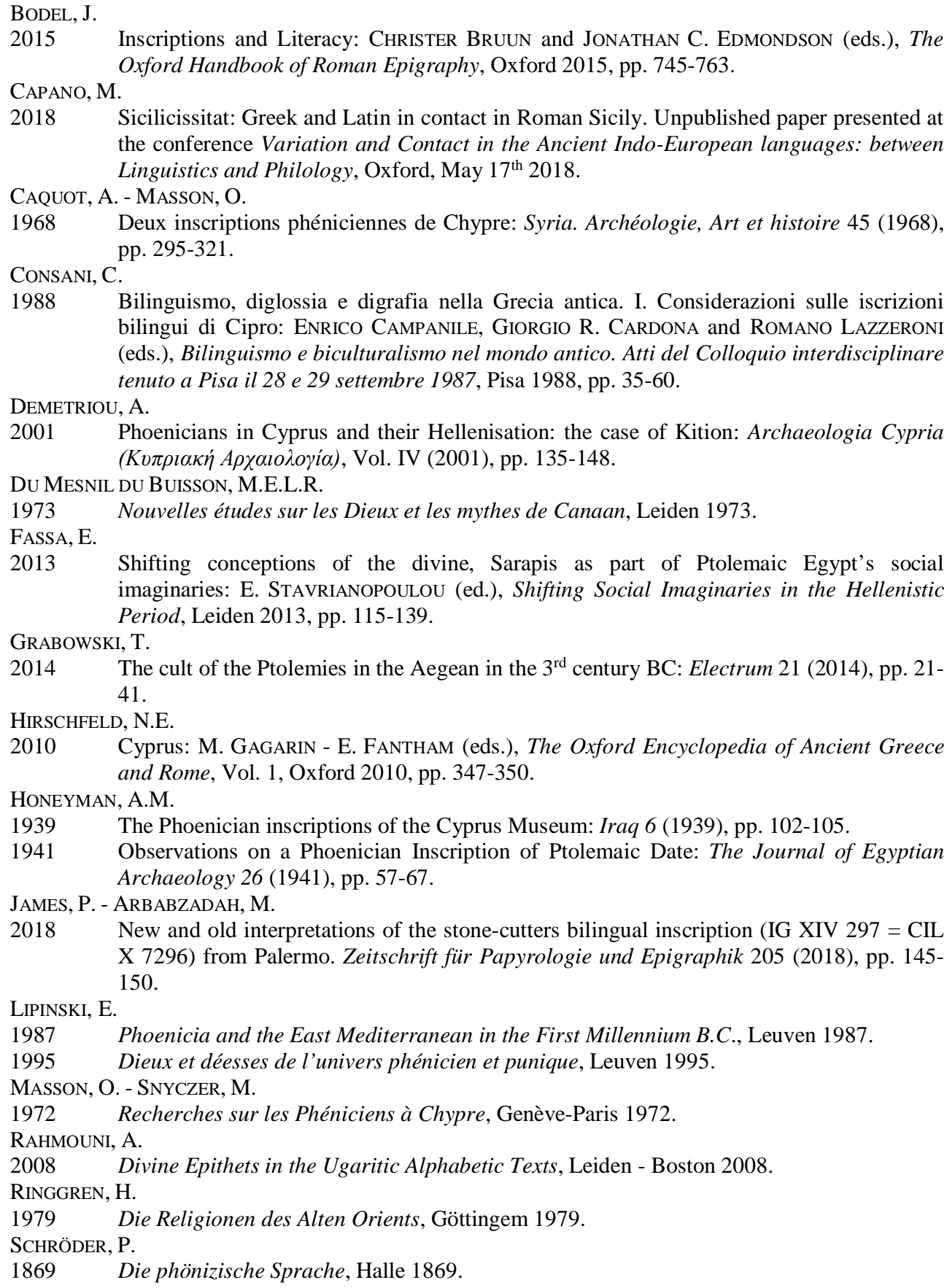

2010 Cyprus: M. Gagarin - E. Fantham (eds.), The Oxford Encyclopedia of Ancient Greece and Rome, Vol. 1, Oxford 2010, pp. 347-350.

HONEYMAN, A.M.

1939 The Phoenician inscriptions of the Cyprus Museum: Iraq 6 (1939), pp. 102-105.

1941 Observations on a Phoenician Inscription of Ptolemaic Date: The Journal of Egyptian Archaeology 26 (1941), pp. 57-67.

JAMES, P. - ARBABZADAH, M.

2018 New and old interpretations of the stone-cutters bilingual inscription (IG XIV 297 = CIL X 7296) from Palermo. Zeitschrift für Papyrologie und Epigraphik 205 (2018), pp. 145150.

LIPINSKI, E.

$1987 \quad$ Phoenicia and the East Mediterranean in the First Millennium B.C., Leuven 1987.

1995 Dieux et déesses de l'univers phénicien et punique, Leuven 1995.

MASSON, O. - SNYCZER, M.

1972 Recherches sur les Phéniciens à Chypre, Genève-Paris 1972.

RAHMOUNI, A.

2008 Divine Epithets in the Ugaritic Alphabetic Texts, Leiden - Boston 2008.

RINGGREN, H.

1979 Die Religionen des Alten Orients, Göttingem 1979.

SCHRÖDER, P.

1869 Die phönizische Sprache, Halle 1869. 
STEELE, $\mathrm{P}$.

2013 A Linguistic History of Ancient Cyprus The Non-Greek Languages, and their Relations with Greek, c.1600-300 BC, Cambridge 2013.

TRIBUlato, O.

2012 The Stone-Cutter's Bilingual Inscription from Palermo (IG XIV 297 = CIL X 7296): A New Interpretation. Zeitschrift für Papyrologie und Epigraphik 177 (2012), pp. 131-140.

VOGÜÉ, M. DE

1867 Inscriptions phéniciennes de l'île de Chypre: Journal Asiatique 10 (1867), pp. 120-124.

YON, M.

$2004 \quad$ Kition dans les textes, Paris 2004. 